\title{
DINAMISM ȘI STABILITATE ÎN RECEPTAREA STRUCTURILOR SIMBOLICE
}

\section{Delia SUIOGAN*}

\section{Dynamism and Stability in the Reception of Symbolic Structures}

\begin{abstract}
The present article aims to (re)discuss the tradition-innovation-invention relationship regarded from the perspective of an open character of traditional culture. This type of openness does not only imply forgetting about the meanings of certain gestures, expressions, imagines, as it has been constantly acknowledged nowadays, but it also suggests continuity in terms of significance and functionality. We will further refer to structures of roles as symbolic works which are capable to reveal their original purposes beyond time and space, clearly entailing the ability to adapt meanings to new contexts. Functions of symbols are crucial. The practical part considers discussing the manner in which the wake service as a symbolic act has preserved its ancient purposes while adding elements of innovation/ invention.
\end{abstract}

Keywords: symbolism, myth, interpretation, role, innovation, stability

Vom (re)aduce în discuție în acest material rolul simbolului în înțelegerea modului în care omul tuturor timpurilor s-a raportat la loc, vreme, devenire. Structurile simbolice la care vom face trimitere fac parte dintr-un obicei care implică în mod evident existența unor structuri de rol. Vom vorbi despre priveghi, nu printr-o simplă contextualizare, ceremonialul funerar, ci urmărindu-1 în relație cu mai multe obiceiuri, toate având un element comun: nevoia asumării unei morți pentru a face posibilă o renaștere. Așadar, vom pune priveghiul în relaţie cu Ajunul, urmărit în relație cu vârstele timpului calendaristic, dar și uman.

În acest context, ceea ce pare, poate, o simplă secvență de ritual, poate fi interpretat drept o opera simbolică în sine, deoarece elementele pe care acest text complex ni le propune sunt mai mult decît par la o primă lectură.

Pornim în acest sens interpretarea noastră de la afirmația Germinăi Comănici, potrivit căreia „omul trăiește în general într-o lume semnificantă, pe care cultura o dezvăluie la modul asimilării și dirijării după intenţionalităţi și finalității concrete /.../ Elementele vehiculate în performarea modelelor de rol în obiceiurile populare sunt caracterizate printr-un accentuat simbolism."1 După părerea noastră, obiceiurile vechi,

* Conf. univ. dr., Universitatea Tehnică din Cluj-Napoca, Facultatea de Litere, str. Victoriei,nr. 76, Baia Mare (delia.suiogan@cunbm.utcluj.ro).

${ }^{1}$ Germina Comănici, Cercul vieții. Roluri și performanță în obiceiurile populare, Editura Paideia, București, 2001, p. 28 
aduse în planul contemporaneităţii, își păstrează acest caracter simbolic. Vom încerca să demonstrăm acest lucru în paginile care urmează.

Simbolismul trebuie privit ca un limbaj capabil să transmită dincolo de timp şi de spaţii o serie întreagă de sensuri, care ar fi putut fi considerate pierdute sau chiar inexistente. „Simbolismul este un vechi limbaj, catalizator universal care relevă complicate percepte și credințe, împărtășind informații și stârnind emoții mai puternice decât un întreg dosar. Este într-adevăr o formă internațională de comunicare ce depășește barierele de limbă, istorie, naționalitate, cultură și religie", , afirma și Clare Gibson

Structurile de rol pot fi privite drept opere simbolice, ele includ elemente ce vorbesc despre un mod de a fi, despre un mod de a gândi lumea şi interacțiunea cu aceasta. Majoritatea cercetărilor asupra operelor simbolice vorbesc despre o dublă întemeiere a operei simbolice: „,nevoia de a vizualiza abstractul și nevoia de a transcede vizibilul.".3

Pentru a înțelege corect toate caracteristicile structurilor de rol de la nivelul obiceiurilor este nevoie de interpretarea corectă a relației dintre elementele componente și context, aceasta pentru că ele se construiesc ca un text coerent ce se cere citit. După cum bine știm, orice text, de orice natură ar fi el, poate fi interpretat.

Cultura populară, în care au luat naștere obiceiurile la care ne vom referi, este una de tip simbolic, iar acest lucru a fost evidențiat de foarte mulți cercetători de-a lungul timpului. Iată una din părerile care ne vor folosi în interpretarea pe care o propunem cu referință directă la natura simbolică a cestei culturi „,ăci nu atât sistemul de gândire și de exprimare metaforică, ci sistemul de simboluri domină /.../. Simbolismul în cultura folclorică nu este un simbolism deschis, ci cvasi-ermetic, cu valori și sensuri cimentate, cu posibilități de inovație reglate."

De aceea, vom fi de acord că orice interpretarea unui fapt folcloric „se obiectivează într-o interpretare sau o hermeneutică a simbolurilor și constelațiilor simbolice. O interpretare nu epuizează simbolul, nici pluralitatea totală a interpretărilor."

Orice operă simbolică este caracterizată de depășirea mimeticului, având la bază transfigurarea simbolică a realității, ,în lumea arhaică a omului religios, simbolul este în același timp realitate și semn. Simbolul este realitatea efectivă pe care o simbolizează, dar, totodată, semnul acelei realități. El poate fi o prelungire a hierofaniei sau o revelație autonomă. Pentru omul ahaic, simbolurile revelează o modalitate a realului sau o structură a lumii care nu este evidentă în planul experienței imediate, care

\footnotetext{
${ }^{2}$ Clare Gibson, Semne și simboluri, Editura Aquila '93, Oradea, 1998, p. 7.

${ }^{3}$ Gabriel Liiceanu, Om și simbol, Editura Humanitas, București, 2005, p. 7.

${ }^{4}$ Germina Comănici, op. cit., pp. 28-29.

${ }^{5}$ Ioan Marchiș, Simbolica artelor non-verbale, Editura Ethnologica, Baia Mare, 2011, p. 60 .
} 
are caracteristicile reacțiilor adaptive și ale operaționalității. Dar tocmai de aici vine conotația religioasă a simbolurilor arhaice: ele vizează mereu ceva real sau o structură a lumii, care, inevitabil, aparțin sacrului.",6

Asistăm, așadar, la o selecție a acelor elemente din realitate care au puterea de a defini cel mai bine intenţia de transmitere a unui mesaj. De cele mai multe ori, selecția presupune o atentă identificare a unor elemente de structură de adâncime iar acest fapt conduce, după părerea noastră, la acea stabilitate sensului, ajungându-se până la identificarea elementului definitoriu al obiectului real vizat.

Simbolismul nu apare dintr-o necesitate pur intelectuală, ci el vine să ne vorbească despre nevoia omului de a atinge nivele superioare de cunoaștere, apelând adeseori la perceptiv și intuitiv. Suntem de acord cu Gabriel Liiceanu în acest sens, ,întreaga soartă a operei simbolice se joacă pe reușita acestei operațiuni paradoxale: trecerea dintr-un mod al existenței în altul, de la eikon la eidos. "7 Asistăm în fapt la o traducere a realității, pentru a o face accesibilă la nivel de semnificație.

Limbajul specific operei simbolice este de natură sintetică și nu analitică, acest fapt duce la păstrarea sincretismului între sensul real şi sensul simbolic. Sinteza înseamnă selecție, așa cum observam și mai înainte, ceea ce contribuie la creșterea puterii simbolismului de a transmite mesaje. Acest tip de limbaj nu apelează la semne arbitrare, ci motivate, având la bază relația dintre semn și lucrul semnificat, el se naște ca o interpretare a lumii, devenind semnul unei prezențe în Lume a celui care comunică și se comunică.

În mod evident, trebuie să aducem în discuţie relaţia dintre opera simbolică și mit, pentru că, așa cum afirma Gabriel Liiceanu, „,̂n acest perimetru se rezolvă problema recuzitei simbolice ca raport între limbajul simbolic și interpretare/.../Acest fond aperceptiv, care mijlocește lectura spontană a simbolului, este de fapt un limbaj de tip special, o mitologie. Mitologiile sunt depozite de sensuri așezate pe un teren epic de factură religioasă. În orice mitologie se rezolvă, sub forma unor imagini epice particulare, suma problemelor existențiale ale unei comunități - geneze, etiologii și în general sensuri trans-empirice acordate tuturor secțiunilor care alcătuiesc experiența de viață a grupului respectiv. Orice mitologie este astfel o uriașă simbolică creată și menținută de o conștiință colectivă într-un răstimp istoric." 8

În cadrul structurilor de rol, actantul/actorul devine reprezentantul unei colectivități prin actualizarea unui text sau unui discurs aparținând

\footnotetext{
${ }^{6}$ Aurel Codoban, Sacru și ontofanie. Pentru o nouă filosofie a religiilor, Editura Polirom, Iași, 1998, p. 83.

${ }^{7}$ Gabriel Liiceanu, op.cit., p. 23.

${ }^{8}$ ibidem, p.44.
} 
acesteia. Actualizarea poate produce inovația, dialogul între performer și sensul textului rămâne mereu viu, nimic nu se execută gratuit sau din inerție, se respectă modelul, pentru a se asigura eficiența actului comunicării, în același timp asumarea totală a participării generează adăugarea de plusvaloare în ideea unei prezentificări a sensului. „Jocul pornește de la aparență, care, îndoindu-se de sine, își propune o altă esență. propunând o altă regulă decât cea reală, jocul, constituie o modificare de esență și nu de aparență. Jocul este o <<esenţă a esenței $>>$. Esența își propune o supraesență, făcând ca aparența (care se află în criză) să cadă în sfera esenței, să se esențializeze, din moment ce ceea ce a fost esență prima dată a alunecat în supraesență."

Devine această modalitate de exprimare un mod de a fi în Lume, caracteristic oricărui timp. Jocurile și măștile specifice fiecărui joc ne apar ca forma cea mai complexă a unui ritual de inițiere în formele de asumare a participării la tot ceea ce înseamnă devenire și întemeiere a ființei. Omul dintotdeauna și de oriunde va apela la această modalitate de a se cunoaște atât ca Sine individual, cât și ca un Sine colectiv.

Simbolul joacă un rol determinant în acest context. „Simbolul păstrează, cu totul altfel decât conceptul, contactul cu sursele profunde ale vieții. Ceea ce ne revelează el este că modalitățile spiritului sunt în același timp manifestări ale vieții, și, în consecință, angajează direct existența umană. Prin aceasta, simbolul devine capabil să dezvăluie solidaritatea dintre structurile vieții umane și cele cosmice și să deschidă omul celorlalte cosmosuri, fără alienare. Omul nu mai este un fragment izolat și impermeabil, lumea îi vorbește grație simbolului și existența sa primește o semnificație transindividuală, experiența individuală se transmută în act spiritual." ${ }^{10}$

Priveghiul poate fi privit ca operă simbolică tocmai datorită complexității structurilor simbolice pe care ni le propune. În ultimul timp, sa ajuns la o anulare a unora dintre valorile de semnificație, datorată prezenței tot mai mult a gratuității, sau/și a imitării la nivelul acțiunilor sale, chiar și în cadrul unor acte ce țin de sărbătoare și sărbătoresc. Acest fapt a condus la pierderea contactului cu sensurile de origine, nemairealizându-se relația dintre acțiunea de codare și cea de decodare. $\mathrm{Cu}$ toate acestea, considerăm că se poate vorbi despre o stabilitate la nivelul receptării functiiilor.

Priveghiul apare în directă relaţie cu o ruptură apărută între două etape. Cel mai bine putem defini priveghiul ca opera simbolică prin intermediul imaginii Ajunului. Toate marile sărbători care presupun trecerea dintr-o treaptă inferioară într-una superioară, care implică anularea unei stări

\footnotetext{
${ }^{9}$ Ioan Marchis, op. cit., p. 159.

${ }^{10}$ Aurel Codoban, op. cit., p. 84.
} 
de dezordine în una de armonie sunt precedate de Ajun. În cadrul Ajunului, vom întâlni priveghiul ca modalitate de realizare a unei treceri/schimbări de statut sub semnul firescului. Priveghiul din cadrul ceremonialului funerar, prezent în cele două nopți în care defunctul rămâne în casa sa, intră în aceeași categorie, are valoarea unui ajun extins.

Fie că vorbim despre Ajunul Anului Nou, despre Ajunul Crăciunului, al Sfântului Nicolae, al Bobotezei, al Paștelui, al Sângeorzului, sau al Sâmedrului, al Sfântului Andrei etc., vom întâlni aceleași gesturi, atitudini, comportamente în cadrul interacțiunii dintre participanții la actele ritualice. Toate ne trimit la actul simbolic al asumării unei stări de limită. Păzirea limitei devine o acțiune deosebit de importantă, cu intenția de evitare a tragicului și de instituire a stării de sublim.

Priveghiul presupune prezența mai multor limbaje, capabile să ne dezvăluie natura simbolică a acestuia. Cele mai importante ni se par limbajele nonverbale, dar mai ales elementele de paralimbaj.

Mediind între dezordine și ordine, actanții performează, conștient sau inconștient, o serie de gesturi, adoptă anumite posturi ale corpului, expresii faciale, tonuri ale vocii. Toate acestea vin să comunice participarea la un act de întemeiere.

Orice Ajun presupune, așadar, o priveghere, o petrecere a timpului îmbătrânit, deteriorat și crearea cadrului necesar nașterii unui timp nou. În cadrul ceremonialului funerar, priveghiul presupune petrecerea celui ce și-a dus la bun sfârșit destinul și asigurarea că defunctul va continua devenirea sa ca strămoș, încheind astfel călătoria sa iniţiatică printr-o întemeiere cosmică.

Rolul pe care trebuie să îl asume actanții este unul deosebit de complex. De cele mai multe ori, astăzi, nu mai putem vorbi despre o participare total conștientă; aceasta nu înseamnă că structura simbolică a dispărut. Lucrul este evident în faptul că aceleași formule de comunicare se repetă de fiecare dată, așa cum observam și mai sus, iar efectul vizat este același. Simbolurile prezente au puterea de a menține activă legătura dintre om și cosmos.

Structurile simbolice din clasa paralimbajului de tipul intensitatea spunerii, ritmul spunerii, calitatea vorbirii, volumul vocii sunt foarte importante în contextual interpretării noastre. La început, în prima etapă de desfășurare a secvențelor specifice Ajunului, actanții apelează la un ton scăzut al vocii, ritmul este mai lent, calitatea vorbirii ține mai mult de o valoare pur afectivă - toate acestea pot fi considerate indici ai nesiguranței, ai temerii, dar și ai bunăvoinței, protecției. În cea de-a doua etapă se trece prin înlocuirea liniștii cu zgomotul; din acest moment ritmul este mai alert, tonul vocilor este mai înalt iar vorbirea primește valențe mai grave. Se trece la o atitudine de siguranță, de curaj. 
În prima etapă, până la miezul nopții, actanții se află încă în relație cu vechiul, sunt puși sub puterea neordinii, care generează sentimentul de frică. Zgomotele, jocurile de la miezul nopții, râsul și plânsul, suspinul vin să anuleze această stare de fapt.

Privegherea are rolul de a ,păzi” ca toate acestea să se întâmple. Curățirea caselor, spălarea ritualică, ospățul, nesomnul, aprinderea, stingerea ritualică și reaprinderea luminilor/focurilor/lumânărilor, împărțirea pâinii și a altor alimente cu valoare simbolică, schimburile de daruri, lovirea reciprocă sau contactul cu diferite ramuri verzi etc. vin să se alăture ca structuri simbolice celor din clasa paralimbajului în definirea priveghiului ca operă simbolică. Toate aceste ,jocuri” ce implică și asumarea unor măști se construiesc într-un ritual complex de iniţiere și de învățare a întemeierii ca modalităţi de participare la ființare.

Vom fi de acord cu Luc Benoist, ,gestul devine prin repetare un adevărat semn instituțional, comunicare a unei noțiuni și, curând, sugestie a unui gând. Căci există în filiația gestului o analogie frapantă între formarea unei obișnuințe, înțelegerea unui fenomen și nașterea unui simbol." "11

Gesturile, atitudinile, acțiunile pe care le repetăm țin de o moștenire culturală și, chiar dacă nu le actualizăm ca sens uneori, ele țin de identitatea noastră, ele ne permit să aparținem și să devenim continuu.

Toate lucrurile sunt în mișcare, modul de raportare a omului la receptarea unor structuri simbolice este dinamic, însă se poate observa cu ușurință că această deschidere se produce într-o închidere oarecare, identificându-se forme de stabilitate în toate formele de comunicare, fapt ce permite posibilitatea transmiterii mesajului de la o generaţie la alta.

\section{Bibliografie:}

Benoist 1995 = Luc Benoist, Semne,simboluri și mituri, București, Editura Humanitas

Codoban 1998 = Aurel Codoban, Sacru și ontofanie. Pentru o nouă filosofie a religiilor, Iași, Editura Polirom

Comănici 2001 = Germina Comănici, Cercul vieții. Roluri și performanță în obiceiurile populare, București, Editura Paideia

Gibson 1998 = Clare Gibson, Semne și simboluri, Oradea, Editura Aquila '93

Liiceanu 2005 = Gabriel Liiceanu, Om și simbol, București, Editura Humanitas

Marchiș 2011 = Ioan Marchiș, Simbolica artelor non-verbale, Baia Mare, Editura Ethnologica

${ }^{11}$ Luc Benoist, Semne, simboluri și mituri, Editura Humanitas, București, 1995, p. 16. 


\section{Alte surse bibliografice:}

Boncompagni 2004 = Solas Boncompagni, Lumea Simbolurilor: numere, litere și figuri geometrice, București, Editura Humanitas

Guénon 1997 = René Guénon, Simboluri ale științei sacre, București, Editura Humanitas 